\title{
Effectiveness of Dolomite on Growth and Yield of Maize (Zea mays 1.) in Dry Land
}

\author{
Amik Krismawati* Evy Latifah and Sugiono
}

\author{
Assessment Institute for Agricultural Technology of East Java, Malang, Indonesia \\ *Corresponding author. E mail: krismawati_amik@yahoo.com
}

\begin{abstract}
The study had been conducted in dry land a site in East Java was in Kediri District during the rainy season I, 2018 2019. The research was designed in RBD, 4 replicates, and 6 treatments, namely : $\mathrm{A}=$ without fertilizer, $\mathrm{B}=300 \mathrm{Urea}$ ha-1 + 400 kg NPK Phonska ha-1 (Recommended Rates of Inorganic Fertilizers or RRIF), C $=$ RRIF + 1 ton dolomite ha-1, D = RRIF + 2 tons dolomite ha-1, E = RRIF + 3 tons dolomite ha-1, and F = RRIF + 4 tons dolomite ha-1 Data analysis used ANOVA (Analysis of Variance) and followed by DMRT test 5\%. The results showed that the application of RRIF + 4 tons dolomite ha-1 obtained of dry seeds yield of corn 7.68 tons ha-1 (increased of 23.87\%) from the RRIF, B/C-ratio 1.73, and R/C-ratio 2.36. Fertilizers treatment F $=$ RRIF +4 tons dolomite ha-1 showed it effectiveness with effectiveness of $174.4 \%$ (RAE > 100\%).
\end{abstract}

Keywords: Dolomite, Zea mays I., Dry land.

\section{INTRODUCTION}

Dolomite is a lime that is widely used in Indonesia. Dolomite contains a lot of $\mathrm{Mg}$ and $\mathrm{Ca}$ which are soil calcifiers, so the application of lime in acid soils has a good effect on soil properties [1]. Dolomite is produced using lime as raw material which has high levels of calcium $(\mathrm{CaO})$ and Magnesium $(\mathrm{MgO})$. Dolomite contains $\mathrm{MgO}=18-24 \%, \mathrm{CaO}=30 \%$, water $=0.19 \%$, $\mathrm{Al} 2 \mathrm{O} 3+\mathrm{Fe} 2 \mathrm{O} 3<3 \%$, and $\mathrm{SiO} 2<3 \%$. The advantages of using dolomite can neutralize soil $\mathrm{pH}$, increase root growth, and improve soil structure [2].

With liming the $\mathrm{pH}$ of the soil increased the supply of nutrients $\mathrm{Mg}$ and $\mathrm{Ca}$ which can shift the position of $\mathrm{H}+$ on the surface of the colloid so that it neutralizes the acidity of the soil. Liming also aims to reduce the risk of $\mathrm{Al}$ poisoning, increased the availability of soil $\mathrm{P}$ elements so that the results of $\mathrm{P}$ release and Al-P and $\mathrm{Fe}-\mathrm{P}$ bonds increased $\mathrm{N}$ fixation and $\mathrm{N}$ mineralization, increased CEC [3].

Dolomite lime contains nutrients Magnesium (Mg) and nutrient elements Calcium in the form of flour $(\mathrm{Ca})$. Provision of dolomite can increased the availability of $\mathrm{Ca}$ and $\mathrm{Mg}$ in the soil. To neutralize the $\mathrm{pH}$ of the soil so that it will increase the level of soil fertility and improve soil physical properties. Dolomite is formed from the reaction between the elements $\mathrm{Mg}$ with limestone. Dolomite formation takes place in seawater and the required element of $\mathrm{Mg}$ is derived from the dissociation (decomposition) of $\mathrm{MgCO} 3$ salt contained in seawater (seawater contains many different types of salt between $\mathrm{MgCO} 3$ and $\mathrm{CaCO} 3$ [4, 5].

Excessive application of inorganic fertilizers can cause plants to lack magnesium, and excessive application of nitrogen fertilizers can acidify the soil. To improve balance nutrients and increased land productivity, additional soil enhancers are needed. Provision of "Rubi" dolomite soil enhancers will improve soil quality by avoiding excess acidic properties due to excessive inorganic fertilizer application. One of the advantages of the "Rubi" dolomite soil enhancer is: (a) has the same grain size $100 \%$ passes 25 mesh sieve and $99.79 \%$ passes 80 mesh ieve and (b) $\mathrm{MgO}$ content $=21.17$ and $\mathrm{CaO}$ content $=$ $29.69 \%$ needed by plants. Dolomite $(\mathrm{CaMg}(\mathrm{CO} 3) 2)$ is an agricultural lime that contains $\mathrm{Ca}$ and $\mathrm{Mg}$ nutrients. Dolomite is a type of compact limestone consisting of a calcium carbonate (contain $22 \%$ calcium) and magnecium carbonate (contain $12 \% \mathrm{Mg}$ ). In agriculture applications, dolomite is commonly used as soil fertilizer in a range of soils. Application of calcium in the form of dolomite, which is a calcium-releasing compound, could be used to increase calcium $[6,7]$. 
Calcium in dolomite plays an important role involving processes that preserve the structural and functional integrity of the plant membrane by stabilizing cell wall structures, leading to strengthening of plant tissues [8]. Calcium is an element that is immobile in the plant, it should be applied to the plant during the early stage of growth, owing to the fact that calcium uptake by the root is rapid and linear in the early developmental stages thereby enhancing stabilization of the cell wall and membrane integrity. These characteristics decline distinctly, continuing until harvest $[9,10]$.

Liming considerably affected the soil $\mathrm{pH}$ and plant available $\mathrm{P}$ status, as $\mathrm{pH}(\mathrm{KCl})$ raised by $2.62 \mathrm{pH}$ units and $\mathrm{Al}-\mathrm{P} 2 \mathrm{O} 5$ by $5.65 \mathrm{mg} 100 \mathrm{~g}-1$ at the highest dolomite rate two years after application. Liming also increased crops yield in all years, but there were no significant differences between treatments with 10 and 15 tha-1 dolomite for maize yield, implying that effect of liming with lower dose could last for several years [11]. Objectives of the research were to evaluate the effect of dolomit application on growth and yield maize in dry land.

\section{MATERIAL AND METHODS}

The research was conducted on dry land areas in Kediri District. The research was performed rainy season during rainy season I, from October 2018 to January 2019. The research was designed in Randomized Block Design (RBD), 4 replicates, and 6 treatments. The observed treatments were as follow:

$\mathrm{A}=$ without fertilizer,

$\mathrm{B}=300$ Urea ha-1 + $400 \mathrm{~kg}$ NPK Phonska ha-1 (Recommended Rates of Inorganic Fertilizers or RRIF),

$\mathrm{C}=\mathrm{RRIF}+1$ tons dolomite ha-1,

$\mathrm{D}=\mathrm{RRIF}+2$ tons dolomite ha-1,

$\mathrm{E}=\mathrm{RRIF}+3$ tons dolomite ha-1,

$\mathrm{F}=\mathrm{RRIF}+4$ tons dolomite ha-1.
The research used plot of $8.0 \mathrm{~m} \times 5.0 \mathrm{~m}$, inter plot by a drainage channel with a width of $30 \mathrm{~cm}$ and a depth of $25 \mathrm{~cm}$. The planted maize variety was hybrid BISI18 with spacing $75 \mathrm{~cm} \times 20 \mathrm{~cm}$ and 1 seed per hole. Soil enhancer used dolomite brand"Rubi", and the inorganic fertilizers used Urea and NPK Phonska (Table 1).

The resulted soil enhancer of dolomite is tested in laboratory to study the level of $\mathrm{Mg}(\%), \mathrm{CaO}(\%)$, $\mathrm{Al} 2 \mathrm{O} 3+\mathrm{Fe} 2 \mathrm{O} 3(\%), \mathrm{SiO} 2(\%), \mathrm{CaCO} 3(\%)$, moisture (\%), fineness: pass through 20 mesh and 80 mesh. The test was conducted at Laboratory of Chemistry, PT Sucofindo Surabaya East Java 2018.

The application of dolomite was spreaded on the surface at the same time as tillage. Dolomite was disseminated in the morning before the wind blows hard. One third dose of Urea was each applied at 21, 42, and 63 DAP (Days After Planting), and NPK Phonska was applied during planting. Weeding, irrigation, and pest control were performed if necessary.

Measuring plant height was performed on 20 samples of plant from ground level to the highest leaf tip. Yield of grains was weighed for each treatment. Sample of the composite soil (chemical properties) was taken from the depth of 0 to $20 \mathrm{~cm}$ in 5 spots using drill of 1 inch size. Soil samples were missed and the composite was taken $\pm 0.5 \mathrm{~kg}$ to be analyzed in laboratory.

Data were analyzed statistically using SAS program over the observed variables using Analysis of Variance (ANOVA) with trust interval of 5\% and Duncan's test (DMRT $=$ Duncan Multiple Range Test) at level 5\% for the significant different effects of the variables [12, 13]. Effectiveness for soil enhancer of dolomite brand "Rubi" is approached using Relative Agronomic Effectiveness (RAE) method [14].

Each treatment is tested against standard fertilizer (in this test is treatment B). RAE is ratio between the increasing yield following the application of fertilizer and the increasing yield after using standard fertilizer, and multiplied by 100 [15].

Table 1. Analysis results of the nutrient contents of soil enhancer of dolomite brand "Rubi"

\begin{tabular}{|c|l|l|l|l|}
\hline Number & Test Parameters & Results & Unit & Metode \\
\hline 1. & $\mathrm{MgO}$ content & 21.17 & $\%$ & SNI 02-2804-2005 (point 6.1) \\
\hline 2. & $\mathrm{CaO}$ content & 29.69 & $\%$ & SNI 02-2804-2005 (point 6.2) \\
\hline 3. & $\mathrm{Al}_{2} \mathrm{O}_{3}+\mathrm{Fe}_{2} \mathrm{O}_{3}$ content & 0.2 & $\%$ & SNI 02-2804-2005 (point 6.3) \\
\hline 4. & $\mathrm{Humidity}$ & 0.12 & $\%$ & SNI 02-2804-2005 (point 6.4) \\
\hline 6. & $\mathrm{SiO}_{2}$ content & 106.41 & $\%$ & SNI 02-2804-2005 (point 6.5) \\
\hline 7. & $\mathrm{CaCO}_{3}$ content & 0.03 & $\%$ & SNI 02-2804-2005 (point 6.7) \\
\hline 8. & level of smoothness : Pass through 25 mesh & 100 & $\%$ & \\
\hline 9 & Pass through 80 mesh & 99.97 & $\%$ & \\
\hline
\end{tabular}


Table 2. Soil analysis results before the research performed at Kediri District

\begin{tabular}{|c|c|c|c|c|c|}
\hline No & $\begin{array}{l}\text { Soil Chemical } \\
\text { Properties }\end{array}$ & Results & Unit & Method & Category \\
\hline \multirow[t]{2}{*}{1.} & $\mathrm{pH} \mathrm{H} 2 \mathrm{O}$ & 6,4 & - & (1:5), elektrometry, pH meter & Slightly acid \\
\hline & $\mathrm{pH} \mathrm{KCl}$ & 6 & - & (1:5), elektrometry, pH meter & Neutral \\
\hline 2. & C-organic & 1 & $\%$ & $\begin{array}{l}\text { Wakley \& } \quad \text { Black; } \\
\text { Spectrophotometry }\end{array}$ & Low \\
\hline 3. & $\mathrm{~N}$ total & 0,15 & $\%$ & Kjeldahl, Titrimetry & Low \\
\hline 4. & P2O5 Bray 1 & 18,86 & ppm & Olsen, Spectrophotometry & Medium \\
\hline 5. & K & 0,3 & $\begin{array}{ll}\text { me } & 100 \\
g-1 & \end{array}$ & $\begin{array}{l}\text { Perkolasi NH4, Acetat } 1 \mathrm{M}, \mathrm{pH} \text {, } \\
\text { AAS }\end{array}$ & Medium \\
\hline 6 & $\mathrm{Na}$ & 0,41 & $\begin{array}{ll}\text { me } & 100 \\
g-1 & \end{array}$ & $\begin{array}{l}\text { Perkolasi NH4, Acetat } 1 \mathrm{M}, \mathrm{pH} \text {, } \\
\text { AAS }\end{array}$ & Medium \\
\hline 7 & $\mathrm{Ca}$ & 13,03 & $\begin{array}{ll}\text { me } & 100 \\
g-1 & \end{array}$ & $\begin{array}{l}\text { Perkolasi NH4, Acetat } 1 \mathrm{M}, \mathrm{pH} \text {, } \\
\text { AAS }\end{array}$ & High \\
\hline 8 & $\mathrm{Mg}$ & 1,47 & $\begin{array}{ll}\text { me } & 100 \\
g-1 & \end{array}$ & $\begin{array}{l}\text { Perkolasi NH4, Acetat } 1 \mathrm{M}, \mathrm{pH} 7 \text {, } \\
\text { ASS }\end{array}$ & Very low \\
\hline 9. & $\begin{array}{l}\text { Cation Exchange } \\
\text { Capacity (CEC) }\end{array}$ & 24.12 & $\begin{array}{l}\mathrm{cmol} \quad \mathrm{c} \\
\mathrm{kg}-1\end{array}$ & & Medium \\
\hline 10 & Base Saturation (BS) & 63 & & & High \\
\hline \multirow[t]{5}{*}{11} & Texture & & & & \\
\hline & Sand & 4 & $\%$ & Hidrometer & \\
\hline & Dust & 46 & $\%$ & Hidrometer & \\
\hline & Clay & 50 & $\%$ & Hidrometer & \\
\hline & Class & $\begin{array}{l}\text { Dusty } \\
\text { clay }\end{array}$ & - & $\begin{array}{l}\text { Triangle Tekstur } \\
\text { USDA }\end{array}$ & \\
\hline
\end{tabular}

RAE equation is given below :

$\mathrm{RAE}=\frac{\text { Yield of the tested fertilizer }- \text { control }}{\text { Yield of the standard fertilizer }- \text { control }} \times 100 \%$

Financial analysis on farming operation was performed to find out its properness. Farming analysis used the economic analysis calculation with R/C-ratio (Revenue Cost ratio) or ratio between revenue and cost. Analysis tool for R/C-ratio [16] with equation as follows:

\section{$\mathrm{R} / \mathrm{C}$ ratio $=\mathrm{NPT} / \mathrm{BT}$}

In which, $\mathrm{R} / \mathrm{C}=$ Revenue and Cost Ratio

NPT $=$ Total production value (IDR ha-1)

$\mathrm{BT}=$ Total cost value (IDR ha-1)

If, $\mathrm{R} / \mathrm{C}>1$ : Feasible to be developed

$\mathrm{R} / \mathrm{C}=1:$ Break even

$\mathrm{R} / \mathrm{C}<1$ : Not feasible to be developed

\section{RESULTS AND DISCUSSION}

\subsection{Soil characteristics at study site}

In early test, soil samples were taken to find out soil fertility status and the inhibiting factors of growth at location of the test. Results of analysis on several chemical properties of the soils and the criteria are presented in Table 2.

Results of analysis on chemical properties of the soils according to [17] (Table 2) showed that soil texture is dusty clay, Cation Exchange Capacity (CEC) in the soils is moderate with base cations, such as high $\mathrm{Ca}$, moderate $\mathrm{Mg}$-dd, moderate $\mathrm{K}$, moderate $\mathrm{Na}$, and high Base Saturation (BS) Optimal availability of $\mathrm{P}$ is within the range of neutral $\mathrm{pH}, 6.5-7.0$, while optimal availability of $\mathrm{K}$ is within the range of $\mathrm{pH} 6.5-7.2$. Low $\mathrm{pH}$ is not due to $\mathrm{Al}$ or $\mathrm{Fe}$ activities, but the increase ion $\mathrm{H}+$ that derived from organic acids, such as oxalate, fulphate, citrate, and malate as a result of organic 
material decomposition $[18,19]$. Table 3 presents soil $\mathrm{pH}(\mathrm{H} 2 \mathrm{O}=6.4$ and $\mathrm{KCl}=6.0)$ is slightly acid. According to [20], soil $\mathrm{pH}$ ranges between 5 to 7 is fairly well for corn development, $\mathrm{N}$ total and $\mathrm{C}$-organic are low (1.00), $\mathrm{N}$ total is low, $\mathrm{C} / \mathrm{N}$ ratio is low (6.67), $\mathrm{P}$ and $\mathrm{K}$ contents are moderate. Meanwhile [21], reported that soil $\mathrm{pH}$ below 6.5 may cause $\mathrm{P}$ unavailable because it relates to $\mathrm{Fe}$ and $\mathrm{Al}$, which form insoluble compounds.

Low soil $\mathrm{pH}$ highly effects nutrients availability as reflected by low nutrients availability, such as $\mathrm{N}, \mathrm{P}$, and $\mathrm{K}$. It is due to $\mathrm{K}+$ ion is released from soil absorption complex and filled with $\mathrm{Al}+$ and $\mathrm{H}+$ ions. Such condition is considered acid with sufficient contents of $\mathrm{N}, \mathrm{P}$, and $\mathrm{K}$, but low Cation Exchange Capacity (CEC), so that it requires additional nutrients through the application of NPK fertilizer. While [22] s showed that liming and fertilizing can increase $\mathrm{N}, \mathrm{P}$, and $\mathrm{K}$ uptake and the dry weight of calopogonium plants in liming 4 tons dolomite ha-1, $50 \mathrm{~kg}$ urea ha-1, $250 \mathrm{~kg}$ SP-36 ha1 , and $50 \mathrm{~kg} \mathrm{KCl}$ ha-1.

The treatment combination of $90 \mathrm{~kg}$ ha- $1 \mathrm{~N}, 60$ $\mathrm{kg}$ ha-1 $\mathrm{P}$ and $60 \mathrm{~kg}$ ha- $-1 \mathrm{~K}$ showed the growth rate of the maize plant was directly proportional to the level of $\mathrm{N}$ applied with constant levels of $\mathrm{P}$ and $\mathrm{K}$ providing the basis for developing optimum NPK fertilizer level for the amendment of degraded soil for higher productivity using maize [23].

\subsection{Corn Growth}

\subsubsection{Plant Heigh.}

Results for analysis of variance showed that the application of dolomite brand "Rubi" combined with inorganic fertilizers, which are derived from Urea and NPK Phonska, have significant effects on plant height of corn at 21, 42, and 63 DAP. Results of observation on plants at 21, 42, and 63 DAP are presented in Table 3.

Results of DMRT test by level 5\% at 21 DAP, fertilizer application of $\mathrm{F}=300 \mathrm{~kg}$ Urea ha- $1+400 \mathrm{~kg}$ NPK Phonska ha-1 +4 tons dolomite "Rubi" ha-1 showed the highest growth, but not different from treatment C, D, and E. Results of DMRT test by level $5 \%$ at 42 DAP, fertilizer application of $\mathrm{F}=\mathrm{RRIF}+4$ tons dolomite "Rubi" ha-1 showed the highest growth, but not different from treatment E. Results of DMRT test by level 5\% at $63 \mathrm{DAP}$, treatment $\mathrm{F}=\mathrm{RRIF}+4$ tons dolomite "Rubi" ha-1 showed the highest growth, but not different from treatment D and E. Results of DMRT test by level $5 \%$ at 63 DAP, fertilizer application of $\mathrm{F}=\mathrm{RRIF}+4$ tons dolomite "Rubi" ha1 showed growth increased by $2.73 \%$ compared to treatment $\mathrm{E}$ and increased by $1.87 \%$ compared to treatment F. Plant height growth lowest obtained from treatment A (without inorganic fertilizer and dolomite) was $158.93 \mathrm{~cm}$. It was presumed that the application of dolomite was able to increase soil $\mathrm{pH}$, which is required by the corn and affected by the available fertilizer application for vegetative growth, especially $\mathrm{N}, \mathrm{P}$, and $\mathrm{K}$, which were derived from Urea and NPK Phonska, which is required to promote the plant height.

Observation on plant growth includes plant height and stem diameter at 30 and 60 dap. Results for analysis of variance showed significant effect on plant height at 30 and 60 dap, and then followed by difference test among treatments using DMRT at level $5 \%$.When approaching the harvest time, the application of $250 \mathrm{~kg}$ Urea $+550 \mathrm{~kg}$ NPK (15-10-20) and $350 \mathrm{~kg}$ Urea+ $450 \mathrm{~kg}$ NPK (15-10-20) produce higher plant height and significant difference than without using fertilizer [24].

Interaction of the treatment D2P3 (900 gram dolomite plot- $1+112.5$ gram $\mathrm{N}$ plot- $1+75$ gram $\mathrm{P}$ plot-1 + 37.5 gram K plot-1) showed the highest height

Table 3. Effect of fertilizer application on plant height at 21, 42, and 63 DAP on dry land, rainy season I, 2018 2019, Kediri District

\begin{tabular}{|c|c|c|c|c|}
\hline \multirow{2}{*}{ Code } & \multirow{2}{*}{ Treatments } & \multicolumn{3}{|c|}{ Plant Height (cm) } \\
\hline & & 21 DAP s) & 42 DAPs) & 63 DAPs) \\
\hline A & $\begin{array}{l}0 \text { kg Urea ha-1 + } 0 \text { kg NPK Phonska ha-1 + } 0 \text { dolomite } \\
\text { brand "Rubi" ha-1 }\end{array}$ & $24.00 \mathrm{a}$ & 86.07 a & 158.93 a \\
\hline B & 300 kg Urea ha-1 + 400 kg NPK Phonska ha-1 (RRIF) & $25.40 \mathrm{ab}$ & 97.53 а & $173.00 \mathrm{~b}$ \\
\hline C & RRIF + 1 tons dolomite brand "Rubi" ha-1 & $26.00 \mathrm{abc}$ & $105.07 \mathrm{~b}$ & $177.93 \mathrm{bc}$ \\
\hline $\mathrm{D}$ & RRIF +2 tons dolomite brand "Rubi" ha- 1 & 26,40 abc & $106.67 \mathrm{~b}$ & $180.67 \mathrm{~cd}$ \\
\hline E & RRIF + 3 tons dolomite brand "Rubi" ha-1 & $26.73 \mathrm{bc}$ & $112.47 \mathrm{~cd}$ & $182.20 \mathrm{~cd}$ \\
\hline $\mathrm{F}$ & RRIF + 4 tons dolomite brand "Rubi" ha-1 & $28.73 \mathrm{C}$ & $113.80 \mathrm{~d}$ & $185.60 \mathrm{~d}$ \\
\hline
\end{tabular}

Note : The numbers followed by the same letter in the same column are not significantly different from the DMRT at the 5\%; $n s=$ non significant; $s=$ significant 
Table 4. The effect of fertilizer application on stem diameter at 21, 42, and 63 DAP on dry land, rainy season I, 2018 2019, Kediri District

\begin{tabular}{|c|c|c|c|c|}
\hline \multirow[t]{2}{*}{ Code } & \multirow[t]{2}{*}{ Treatments } & & $\begin{array}{l}\text { Stem Diameter } \\
\qquad(\mathrm{cm})\end{array}$ & \\
\hline & & $21 \mathrm{DAPs})$ & 42 DAPs) & 63 DAPs) \\
\hline A & $\begin{array}{l}0 \text { kg Urea ha-1 + } 0 \text { kg NPK Phonska ha-1 + } 0 \text { dolomite } \\
\text { brand "Rubi" ha-1 }\end{array}$ & 0.50 a & $1.42 \mathrm{a}$ & 1.69 a \\
\hline B & 300 kg Urea ha-1 + 400 kg NPK Phonska ha-1 (RRIF) & $0.71 \mathrm{a}$ & $1.59 \mathrm{~b}$ & $1.87 \mathrm{~b}$ \\
\hline C & RRIF + 1 tons dolomite brand "Rubi" ha- 1 & $0.83 \mathrm{~b}$ & $1.55 \mathrm{~b}$ & $1.91 \mathrm{bc}$ \\
\hline $\mathrm{D}$ & RRIF +2 tons dolomite brand "Rubi" ha- 1 & $0.96 \mathrm{c}$ & $1.64 \mathrm{bc}$ & $1.93 \mathrm{bc}$ \\
\hline $\mathrm{E}$ & RRIF + 3 tons dolomite brand "Rubi" ha-1 & $1.10 \mathrm{~d}$ & $1.68 \mathrm{bc}$ & $1.98 \mathrm{C}$ \\
\hline $\mathrm{F}$ & RRIF + 4 tons dolomite brand "Rubi" ha-1 & $1.12 \mathrm{~d}$ & $1.75 \mathrm{c}$ & $2.10 \mathrm{~d}$ \\
\hline
\end{tabular}

Note : The numbers followed by the same letter in the same column are not significantly different from the DMRT at the $5 \% ; n s=$ non significant; $s=$ significant

of the plant, $217.03 \mathrm{~cm}$ for sweet corn, and it showed significantly different with other treatments, $203.77 \mathrm{~cm}$ on treatment D0P3 (0 gram dolomite +112.5 gram N + 75 gram P plot-1 + 37.5 gram K plot1) and 209.99 cm on treatment D1P3 (450 gram dolomite plot-1 + 112.5 gram $\mathrm{N}$ plot- $1+75$ gram plot- $1+37.5$ gram K plot-1) [25].

The increased height of plant is due to cell division and elongation, which are dominated on the tip part (shoot). The increasing growth of plant is due to the application of dolomite and $\mathrm{N}, \mathrm{P}, \mathrm{K}$ fertilizers in the planting medium. The plant growth keeps increasing along with the increase age [26].

Giving lime can increase soil $\mathrm{pH}$ and create favorable soil environmental conditions for the condition of microorganisms in the soil so that it supports processes that come from the soil so that the $\mathrm{N}$ element is available to plants that affect it on plant vegetative growth in the form of plant height [27].

The main role of $\mathrm{N}$ for plant is to promote the plant growth as a whole, particularly stem, branch, and leaf [28]. N may accelerate the plant growth, particularly stem and leaf. $\mathrm{N}$ availability will increase the photosynthetic rate and the photosynthesis will run well by the availability of $\mathrm{Mg}$ from dolomite and $\mathrm{K}$ from fertilizer. The resulted photosynthate will be translocated to the growing organs of the plant, such as stem, which increase the plant height. $\mathrm{Mg}$ and $\mathrm{K}$ function as chlorophyll composers and activators of diverse enzymes in photosynthetic and respiratory reactions, as well as in RNA and DNA formation [28, 29]. The plant growth is highly affected by environmental factors, such as light and temperature, which play important roles in production and transporting the food matters [30].

Besides dolomite, it requires to add inorganic fertilizers as nutrient sources of $\mathrm{N}, \mathrm{P}$, and $\mathrm{K}$. The $\mathrm{N}$,
$\mathrm{P}, \mathrm{K}, \mathrm{Ca}, \mathrm{Mg}$, and $\mathrm{S}$ belong to essential macronutrients, which are highly required by plant and their functions are irreplaceable by other nutrients, so that if the amount is insufficient, the plant will not grow normally. Sulphur will assist in the formation of chlorophyll; so that the leaf will look green and it increase the content of protein and vitamin [31, 32]. Height of the corn plant has significant effect and positive correlation with numbers of leaf and seeds per ear in which $r=0.484$ and $r=0.592$. It shows that the higher height of the corn plant, the greater numbers of leaf and seed per ear will be produced. Besides that, plant height has positive correlation and strong relationship with weight of seeds and dry weight of corn in which $r=0.721$ and $r=0.700$. It was assumed that such correlation is due to plant height will affects on numbers of leaf and, of course, numbers of leaf will affect on the amount, weight of seeds, and dry weight of corn. Due to leaf is the place where photosynthesis takes place, so that higher photosynthetic process will increase the yield of the plant [33].

The treatment of dolomite fertilizer dosage showed a significant effect on plant height at 4,6 , and 8 weeks after planting (WAP). The best treatment was giving dolomite lime 7,000 kg ha-1 (1,960 gram plot-1) (D3). At the age of $8 \mathrm{WAP}$, the D3 treatment with the tallest plant $(200.06 \mathrm{~cm})$ was significantly different from K1 $(180.39 \mathrm{~cm})$ and K2 $(193.28 \mathrm{~cm})$. The interaction of the two treatments with the highest plant at D3K3 (26.42 $\mathrm{cm})$ [34]. Giving lime can increase soil $\mathrm{pH}$ and create good soil environmental conditions for the conditions of microorganisms in the soil so as to accelerate the process of $\mathrm{N}$ mineralization from the soil so that $\mathrm{N}$ elements are available to plants which affect plant vegetative growth in the form of plant height [34]. 
Table 5. The effect of fertilizer application on Leaf Area (LA) and Leaf Area Index (LAI) of the corn plant at 60 and 90 DAP, dry land, rainy season I, 2018-2019, Kediri District

\begin{tabular}{|c|c|c|c|c|c|}
\hline \multirow{2}{*}{ Code } & \multirow{2}{*}{ Treatments } & \multicolumn{2}{|c|}{$\begin{array}{l}\text { Leaf Area (LA) per Plant } \\
\mathrm{cm} 2\end{array}$} & \multicolumn{2}{|c|}{$\begin{array}{l}\text { Leaf Area Index (LAI) } \\
\text { per plant }\end{array}$} \\
\hline & & 60 DAPs) & 90 DAPs) & 60 DAPs) & 90 \\
\hline A & $\begin{array}{l}0 \text { kg Urea ha-1 + } 0 \text { kg NPK Phonska ha- } 1+0 \\
\text { dolomite brand "Rubi" ha-1 }\end{array}$ & 3.260 a & 3.576 a & $2.430 \mathrm{a}$ & $2.630 \mathrm{a}$ \\
\hline $\mathrm{B}$ & $\begin{array}{l}300 \text { kg Urea ha-1 + } 400 \text { kg NPK Phonska ha-1 } \\
\text { (RRIF) }\end{array}$ & $4.385 \mathrm{~b}$ & $4.643 \mathrm{~b}$ & $3.346 \mathrm{~b}$ & $2.358 \mathrm{~b}$ \\
\hline C & RRIF + 1 tons dolomite brand "Rubi" ha- 1 & $4.744 \mathrm{c}$ & $4.954 \mathrm{C}$ & $3.580 \mathrm{c}$ & $3.740 \mathrm{c}$ \\
\hline $\mathrm{D}$ & RRIF + 2 tons dolomite brand "Rubi" ha- 1 & $5.240 \mathrm{~d}$ & $5.375 \mathrm{~d}$ & $3.875 \mathrm{~d}$ & $4.122 \mathrm{~d}$ \\
\hline $\mathrm{E}$ & RRIF + 3 tons dolomite brand "Rubi" ha- 1 & $5.634 \mathrm{e}$ & $5.774 \mathrm{e}$ & $4.165 \mathrm{e}$ & $4.265 \mathrm{~d}$ \\
\hline \multirow[t]{2}{*}{$\mathrm{F}$} & RRIF + 4 tons dolomite brand "Rubi" ha- 1 & $5.752 \mathrm{e}$ & 5.880 e & $4.323 \mathrm{e}$ & $4.648 \mathrm{~d}$ \\
\hline & CV & 1.37 & 2.15 & 3.10 & 4.71 \\
\hline
\end{tabular}

Note : The numbers followed by the same letter in the same column are not significantly different from the DMRT at the $5 \%$; $n s=$ non significant; $s=$ significant

\subsubsection{Stem Diameter.}

Results for analysis of variance showed that the application of dolomite brand "Rubi" combined with inorganic fertilizers, which are derived from Urea and NPK Phonska, have significant effects on stem diameter of corn at 21, 42, and 63 DAP. Results of observation on plants at 21,42 , and 63 DAP are presented in Table 4 Results of DMRT test by level 5\% at $21 \mathrm{DAP}$, the application of $300 \mathrm{~kg}$ Urea ha- $1+400$ kg NPK Phonska ha-1 +4 tons dolomite "Rubi" ha-1 resulted the greatest stem diameter, but not different from treatment E. Results of DMRT test by level 5\% at 42 DAP, fertilizer application of $\mathrm{F}=300 \mathrm{~kg}$ Urea ha-1 + $400 \mathrm{~kg}$ NPK Phonska ha-1 + 4 tons dolomite "Rubi" ha-1 showed the highest growth, but not different from treatment D and E. Results of DMRT test by level $5 \%$ at 63 DAP, the application of $300 \mathrm{~kg}$ Urea ha-1 + $400 \mathrm{~kg}$ NPK Phonska ha-1 + 4 tons dolomite "Rubi" ha-1 resulted the greatest stem diameter, and significantly different with other treatment.

Results for analysis of variance showed that the application of fertilizer $300 \mathrm{~kg}$ Urea ha- $1+400 \mathrm{~kg}$ NPK Phonska ha-1 +4 tons dolomite "Rubi" ha-1 at 21, 42, and 63 DAP have resulted stem diameter $1.12 \mathrm{~cm}, 1.75$, $\mathrm{cm}, 2.10 \mathrm{~cm}$. At 63 DAP, the treatment $300 \mathrm{~kg}$ Urea ha$1+400$ kg NPK Phonska ha- $1+4$ tons dolomite "Rubi" ha-1 showed significantly different with other treatments and it increased $12.30 \%$ in comparison with fertilizer application with the recommended dosage of inorganic fertilizer (treatment B) Results of DMRT test by level $5 \%$ at $21 \mathrm{DAP}$, the application of $300 \mathrm{~kg}$ Urea ha-1 + $400 \mathrm{~kg}$ NPK Phonska ha-1 + 4 tons dolomite "Rubi" ha-1 resulted the greatest stem diameter, but not different from treatment E. Results of DMRT test by level $5 \%$ at 42 DAP, fertilizer application of $\mathrm{F}=300$ kg Urea ha-1 + 400 kg NPK Phonska ha-1 + 4 tons dolomite "Rubi" ha-1 showed the highest growth, but not different from treatment D and E. Results of DMRT test by level $5 \%$ at 63 DAP, the application of $300 \mathrm{~kg}$ Urea ha-1 + $400 \mathrm{~kg}$ NPK Phonska ha- $1+4$ tons dolomite "Rubi" ha-1 resulted the greatest stem diameter, and significantly different with other treatment.

Stem enlargement does not only depend on nutrient supply, which is absorbed by the plant, but also on genetic factor of the plant. Stem enlargement is due to some factors such as external factor, in which nutrients play important role in the water and transport the nutrients from the soil, and internal factors, which include types or varieties of the plant, most of them are vegetative phase in accordance with the plant height $[35,36]$.

Nutrients and water availability affect the growth or cells extension such as vegetative organs or reproductive organs. Nitrogen functions to increase vegetative growth such as shoot formation, stem and leaf development, the plants look greener, and protein formation, while $\mathrm{K}$ plays its role to increase glucose translocation in protein and amylum formation [37].

Dry weight of plant has positive correlation with stem diameter and weight of roots by $r=0.590$ and $r=$ 0.517 . It shows that the higher diameter of the stem and weight of roots, it will increase dry weight of the plant. It is presumed that tha application of sulphus may reduce soil $\mathrm{pH}$, so that it will increase availability of other nutrients [33]. 
Table 6. The effect of fertilizer application on numbers of seed per cob, weight of 100 seeds, weight per cob, anddry seeds yield of corn with water content 14\%, dry land, rainy season I, 2018 - 2019, Kediri District

\begin{tabular}{|c|c|c|c|c|c|}
\hline Code & Treatments & $\begin{array}{l}\text { Numbers } \\
\text { of seed per } \\
\text { cob } \\
\text { (row s)s) }\end{array}$ & $\begin{array}{l}\text { Weight of } \\
100 \text { seeds } \\
\text { (gram)s) }\end{array}$ & $\begin{array}{l}\text { Weight per } \\
\text { cob } \\
\text { (gram)s) }\end{array}$ & $\begin{array}{l}\text { Dry seeds } \\
\text { yield of } \\
\text { corn } \\
(\text { ton ha-1)s) }\end{array}$ \\
\hline A & $\begin{array}{l}0 \text { kg Urea ha-1 + } 0 \text { kg NPK Phonska ha- } 1+0 \\
\text { dolomite brand "Rubi" ha-1 }\end{array}$ & 13.65 a & 27.50 a & 171.16 a & 4.22 a \\
\hline B & $\begin{array}{l}300 \text { kg Urea ha-1 + } 400 \text { kg } \\
\text { NPK Phonska ha-1 (RRIF) }\end{array}$ & $14.86 \mathrm{~b}$ & $33.00 \mathrm{~b}$ & $218.69 \mathrm{~b}$ & $6.20 \mathrm{~b}$ \\
\hline C & RRIF + 1 tons dolomite brand "Rubi" ha- 1 & $15.60 \mathrm{bc}$ & $33.07 \mathrm{~b}$ & $221.24 b$ & $6.45 \mathrm{~b}$ \\
\hline $\mathrm{D}$ & RRIF +2 tons dolomite brand "Rubi" ha- 1 & $15.84 \mathrm{bc}$ & $33.80 \mathrm{~b}$ & $222.08 \mathrm{~b}$ & $6.84 \mathrm{~b}$ \\
\hline $\mathrm{E}$ & RRIF +3 tons dolomite brand "Rubi" ha- 1 & $16.12 \mathrm{c}$ & $34.07 \mathrm{~b}$ & $225.81 \mathrm{~b}$ & $7.23 \mathrm{c}$ \\
\hline $\mathrm{F}$ & RRIF + 4 tons dolomite brand "Rubi" ha- 1 & $16.43 \mathrm{c}$ & $34.97 \mathrm{~b}$ & $229.70 \mathrm{c}$ & $7.68 \mathrm{~d}$ \\
\hline \multicolumn{2}{|l|}{ CV } & 3.68 & 7,57 & 9,17 & 2,83 \\
\hline
\end{tabular}

Note: The numbers followed by the same letter in the same column are not significantly different from the DMRT at the 5\%; $n s=$ non significant; $s=$ significant

Dolomite is able to provide nutrients in the soil and contains other micro nutrients so that it can support plant growth and development, while the potassium fertilizer given has an optimum and balanced dosage, and plants can absorb the nutrients contained in the fertilizer to carry out good metabolism [38].

The results of the average difference test of stem diameter showed that the effect of dolomite on the largest stem diameter at D3 (22.66 mm) was significantly different from D1 $(18.06 \mathrm{~mm})$ but not significantly different from D2 $(21.33 \mathrm{~mm})$. The effect of potassium fertilizer on producing the largest stem diameter at K3 $(21.70 \mathrm{~mm})$ was significantly different from K1 $(19.37 \mathrm{~mm})$ but not significantly different from K2 $(20.98 \mathrm{~mm})$. The interaction of the two treatments on stem diameter obtained the largest diameter at D3K3 $(23.14 \mathrm{~mm})$ the smallest at D1K1 (15.23 mm) [34].

\subsubsection{Leaf Area (LA) per Plant and Leaf Area Index (LAI)}

Results for analysis of variance showed that the application of dolomite brand "Rubi" combined with inorganic fertilizers, which are derived from Urea and NPK Phonska, have significant effects on Leaf Area and Leaf Area Index of corn. Results of observation on Leaf Area (LA) and Leaf Area Index (LAI) of corn are presented in Table 5.

Results of DMRT test by level $5 \%$ at 60 and 90 DAP, the application of $300 \mathrm{~kg}$ Urea ha- $1+400 \mathrm{~kg}$ NPK Phonska ha-1 +4 tons dolomite "Rubi" ha-1 resulted the greatest Leaf Area, even though it is insignificantly different with $\mathrm{E}$, but it is significantly different with other treatment. Results of DMRT test by level $5 \%$ at 60 DAP, the application of $300 \mathrm{~kg}$ Urea ha$1+400 \mathrm{~kg}$ NPK Phonska ha-1 + 4 tons dolomite "Rubi" ha-1 resulted the greatest Leaf Area Index, even though it is insignificantly different with $\mathrm{E}$, but it is significantly different with other treatment. Results of DMRT test by level $5 \%$ at 90 DAP, the application of $300 \mathrm{~kg}$ Urea ha-1 + $400 \mathrm{~kg}$ NPK Phonska ha- $1+4$ tons dolomite "Rubi" ha-1 resulted the greatest Leaf Area Index, even though it is insignificantly different with D and $\mathrm{E}$, but it is significantly different with other treatment.

Results for analysis of variance showed that the application of fertilizer $300 \mathrm{~kg}$ Urea ha- $1+400 \mathrm{~kg} \mathrm{NPK}$ Phonska ha- $1+4$ tons dolomite "Rubi" ha-1 at 60 and 90 DAP have resulted Leaf Area $5.752 \mathrm{~cm} 2$ and 5.880 $\mathrm{cm} 2$, the treatment $300 \mathrm{~kg}$ Urea ha-1 $+400 \mathrm{~kg}$ NPK Phonska ha- $1+4$ tons dolomite "Rubi" ha-1 increased $31.17 \%$ and $31.75 \%$ in comparison with fertilizer application with the recommended dosage of inorganic fertilizer (treatment B).

Results for analysis of variance showed that the application of fertilizer $300 \mathrm{~kg}$ Urea ha- $1+400 \mathrm{~kg}$ NPK Phonska ha- $1+4$ tons dolomite "Rubi" ha-1 at 60 and 90 DAP have resulted Leaf Area Index 4.323 and 4.648 the treatment $300 \mathrm{~kg}$ Urea ha-1 + $400 \mathrm{~kg}$ NPK Phonska ha-1 +4 tons dolomite "Rubi" ha-1 increased $29.20 \%$ and $89.48 \%$ in comparison with fertilizer application with the recommended dosage of inorganic fertilizer (treatment B).

It is presumed that the greater and denser that plants will stimulate the plants to absorb nutrients, water, and light for their growth. Sufficient nutrients will stimulate 
the plant height and formation of new leaves. Formation of new leaves will increase numbers of leaf, so that total leaf area per plant will increase even though leaf area per individual is small. Leaf area increases and it means that light interception by leaf will increase as well. Leaf as biological place of photosunthesis highly determines interception and change of light energy in seed formation and yield of harvest [40].

Parameter of Leaf Area is used as parameter of observation in order to find out the photosynthetic rate per unit plant, whereas in many cases, most of them is determined by leaf area [41]. Leaf is the place where the plant will change light interception and energy into seed and yield of harvest [42]. Therefore, leaf plays important role for the plant growth. When the leaves grow perfectly, the possibility will directly proportionate with the yield of harvest.

The application of $\mathrm{N}$ on corn showed higher development and more roots in 'early season, may be due to the increase of leaf area and greater amount of assimilation products for the root growth. The application of phosphor may develop more roots than without any fertilizer application, but it may be not the direct effect. At first, $\mathrm{P}$ availability increases the photosynthesis, and then increases the root growth. The increase age of the plant may also affect fresh weight of the canopy due to the effect of water status. Water status of tissues or the whole part of the plant may change along with the increasing age of the plant [39].

At the age of 8 WAP, treatment D3 showed the largest leaf area $(6711.56 \mathrm{~cm} 2)$ was not significantly different from D2 (6476.04 cm2) and D1 (6229.04 $\mathrm{cm} 2)$. In the treatment of potassium fertilizer aged 8 WAP, K3 treatment with the largest leaf area $(6652.48$ $\mathrm{cm} 2$ ) was not significantly different from K2 (6476.04 $\mathrm{cm} 2)$ and $\mathrm{K} 1$ (6125.19 $\mathrm{cm} 2)$. The interaction of dolomite dosage and potassium fertilizer dose on stem diameter corn plants showed no significant effect. The growth of corn plants aged 8 WAP has reached the phase maximum vegetative growth where the vegetative growth phase will stop when it enters the generative growth phase or the first appearance of male flowers on corn plants [40].

Optimal Leaf Area Index for cultivated plants range from 3 to 5. The highest Leaf Area Index (LAI) was 6.18 that was obtained by spacing $75 \mathrm{~cm} \mathrm{x} 40 \mathrm{~cm}$ and dose of manure was 3 ton ha- 1 , and the lowest was 2.98 that was obtained by spacing $80 \mathrm{~cm} \times 20 \mathrm{~cm}$ and dose of manure was 3 ton ha-1 [43].

Photosynthesis on leaf will effect on yield of assimilate and it can be seen on parameter of Leaf Area Index. The wider leaf area surface may enable the plant to intercept light optimally, so that it will also effect on photosynthetic process. Leaf Area Index is derived from leaf area. Leaf Area Index describes measurement of the photosynthetic apparatus, which reflect capacity of actual productivity of the plant in producing photosynthate that finally effect on the increasing growth and development of the plants, which has economic value. Fertilizer plays its role in photosynthetic process due to fertilizer is one of nutrient suppliers, which is needed in metabolism process [44].

Leaf Area Index (LAI) is ratio of green leaf area, which actively photosynthesizes against land area grown by the plants. Optimal LAI values range from 2.96 to 5.93. The higher population of the plants, the greater amount of of leaves and leaf area will be produced by the plant in a given area in comparison with low population. If LAI value is higher (>) 3.0, so that $95 \%$ of the sunlight will be well intercepted, but if LAI value is higher (>) 5.0, the interception decrease due to leaf blade covers to each other [45].

\subsection{Yield Component (Number of Seed per Cob, Weight of 100 Seeds, Weight per Cob and Dry Seeds Yield of Corn).}

Results on analysis of variance showed that the application of dolomite brand "Rubi" and Urea + NPK Phonska have significant effect on number of seed per cob, weight of 100 seeds, weight per cob, and dry seeds yield of corn with $14 \%$ water content. Results of observation on number of seed per cob, weight of 100 seeds, weight per cob, and dry seeds yield of corn with $14 \%$ water content are presented in Table 6.

The highest number of seed per cob, was obtained by the treatment of $F=(300 \mathrm{~kg}$ Urea ha- $1+400 \mathrm{~kg}$ NPK Phonska ha-1 + 4 tons dolomite "Rubi" ha-1) 16.43 even though it did not show significant difference with fertilizer application of C, D, and E or increased $10.57 \%$ in comparison with the recommended rates of inorganic fertilizers (treatment B) 14.86 .

The dosage of NPK fertilizer was $300 \mathrm{~kg}$ ha-1 increased the yield on the number of rows per ear reaching 15.90 rows and $23.05 \mathrm{~cm}$ for the length of the ear. The NPK fertilizer is less than $300 \mathrm{~kg}$ ha-1 has a low yield when compared to a dosage se of $300 \mathrm{~kg}$ ha1. At a dosage of $200 \mathrm{~kg}$ ha-1, variable number of rows reached 14.43 rows, and the length of the cob reached $22.20 \mathrm{~cm} \mathrm{[46,47].}$

The $\mathrm{N}$ and $\mathrm{P}$ elements are continuously absorbed by plants until they are close to maturity, while $\mathrm{K}$ is mainly needed during silking. most of the $\mathrm{N}$ and $\mathrm{P}$ to the growing points, stems, leaves, and male flowers, then transferred to seeds. The number of rows of seeds per corncob is more influenced by genetic factors, so that applying several fertilizer concentrations will produce a relatively equal number of rows of seeds per cob [48, 49]. 
The highest weight of 100 seeds was obtained by the application of fertilizer fertilizer $F=(300 \mathrm{~kg}$ Urea ha-1 + $400 \mathrm{~kg}$ NPK Phonska ha-1 + 4 tons dolomite "Rubi" ha-1) 34.97 gram higher than other treatments even it is statistically non significant except treatment A or increase $5.97 \%$ in comparison with the Recommended Rates of Inorganic Fertilizers (treatment B) 33.00 gram.

Results on analysis of variance toward weight of 100 seeds showed the significant effect of the application of dolomite and inorganic fertilizer Urea + NPK Phonska. Average weight of 100 seeds of corn ranged $33.00-34.97$ gram. Data in Table 6 showed that the application of each dosage dolomite and inorganic fertilizer Urea + NPK Phonska has changed weight of 100 seeds of corn. The increased dosage dolomite into 4 ton ha- 1 has increased weight of 100 seeds of corn for about $27.16 \%$ in comparison with without dolomite application. It was presumed that response of the corn plant toward the application of NPK during the process of seed filling has been sufficient. P plays its role when soil $\mathrm{pH}$ is neutral by the application of dolomite. According to [50], the increased of phosphor supply in the plant body will increase the metabolism, so that the seed filling process will be optimal and weight of seeds will increas as well. Most of phosphor contains in seeds and the other parts contain in young plant.

Dry weights of 100 seeds indicate size and filled out seeds, as well as an indicator of seed quality. The higher dry weight of 100 seeds, the seeds are more qualified. Cob formation and seed filling are description of the photosynthate functions, which are translocated for the development of reproductive organs. Moreover, the increase of dry weight of seeds relates to the amount of photosynthates, which are translocated to the seeds, the increase of nutrients status in the soils and the more favorable rooting system to absorb nutrients from the soils. High photosynthates translocation to reproductive organs may promote ear formation and seed filling, however, the seeds are filled out and have bigger size that depend on development of the photosynthetic organs and the environmental supports [51].

Among different doses, fertilizer applications have significant effect on weight of 100 seeds. The addition of NPK fertilizer, whether complex or single, will be able to increase $\mathrm{P}$ and $\mathrm{K}$ absorption into the seeds than to corn stover. According to [52], the application of inorganic fertilizers through the soils is not completely absorbed by the plants optimally due to the nutrients may be leaching and evaporated.

The different sources of sulphur do not significantly affect on weight of 100 seeds and ear length, but different dosage sulphur significantly affect on weight of 100 seeds and ear length [53].
Potassium functions to improve fruit quality during generative period. Potassium is important for fruit formation Potassium is absorbed and required by corn plants since early growth, flowering, and husk

formation. When the husk formation is completed, $\mathrm{K}$ uptake is stopped [54].

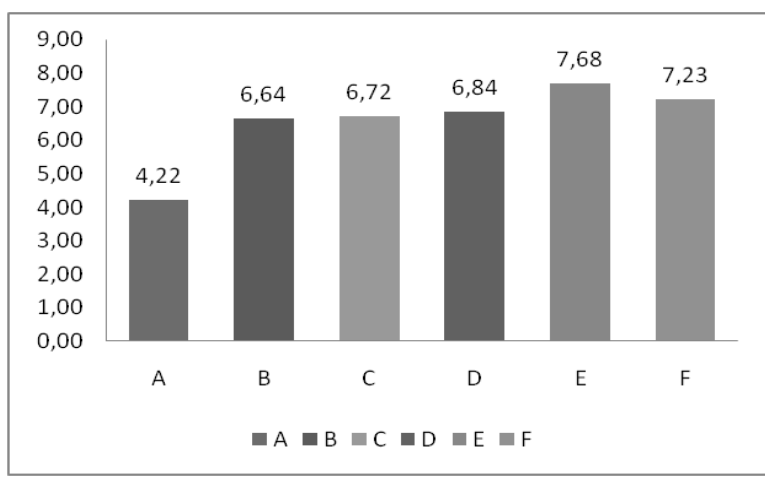

Figure 1. Graphic for dry seeds yield of corn

The highest weight per cob obtained by the application of fertilizer fertilizer $\mathrm{F}=(300 \mathrm{~kg}$ Urea ha- 1 + 400 kg NPK Phonska ha-1 + 4 tons dolomite "Rubi" ha-1) 229.70 gram and significantly different with other treatments or increase $5.03 \%$ in comparison with the the recommended rates of inorganic fertilizers (treatment B) 33.00 gram. The lowest weight per ear was resulted by treatment A, 171.16 gram. It was due to the treatment $\mathrm{F}$ used the highest dosage of dolomite and NPK, so that it has the heaviest weight of cob. According to [14], higher dosage of dolomite and NPK applied, the higher nutrientswill be available from inorganic fertilizer, which has been available for the plant by the treatment, and dolomite contains $\mathrm{Ca}$ and $\mathrm{Mg}$ that are able to increase soil $\mathrm{pH}$.

Fruit formation and filling are highly affected by N, $\mathrm{P}, \mathrm{K}$ that will be used in photosynthetic process as composer of carbohydrate, fat, protein, mineral, and vitamin, which will be translocated to the fruit storage part. P could increase plant production, yield improvement and accelerate seeds and fruits maturation. High growth of plant will increase the photosynthetic process and produce photosynthate that can be translocated for fruit and seed filling, so that weight of ear per sample will be higher as well. The increase of nutrients availability, particularly $\mathrm{P}$, is required for fruit and seed filling on the ear. The application of single inorganic fertilizer, $500 \mathrm{~kg}$ Urea ha- $1+350 \mathrm{~kg}$ TSP ha- $1+300 \mathrm{KCl}$ ha- 1 , weight of ear without husk per plant produces the heaviest ear, 179.03 gram, in comparison with other treatment [55, 56].

Results of DMRT test by level $5 \%$ at 60 and 90 DAP, the application of $\mathrm{F}=(300 \mathrm{~kg}$ Urea ha- $1+400$ kg NPK Phonska ha-1 +4 tons dolomite "Rubi" ha-1 ) resulted the greatest dry seeds yield of corn, 7.68 ton 
ha-1, and significantly different with other treatments or increased the yield $23.87 \%$ in comparison with the application of the recommended rates of inorganic fertilizers (treatment B), 6.20 ton ha-1 (Figure 1).

Moreover [57] suggested that sulphur (S) plays important role in protein synthesis and vitamin in the plants. Besides that, $\mathrm{S}$ is a component of essential amino acids, which is associated with Nitrogen in metabolism, so that $\mathrm{S}$ will be able to increased yield and quality of the plants.

The plant height has significant effect and positive correlation with moderate relationship toward numbers of leaf and numbers of seed per ear by $r=0.484$ and $r$ $=0.592$. It showed that the higher the plants, number of leaf and numbers of seed per ear will increase as well. Furthermore, plant height has positive correlation with strong relationship toward weight of seeds and dry weight of corn by $r=0.721$ and $r=0.700$. It is presumed that the correlation was due to plant height will affect on numbers, weight of seeds, and dry weight of corn. Due to leaf becomes the place where photosynthesis takes place, so that the higher photosynthetic process takes place, the higher yield will be produced [33].

Complexed NPK fertilizers cannot be applied individually, but it must be added with Urea as $\mathrm{N}$ source. The application of NPK $20-10-10$ by dosage $400 \mathrm{~kg} \mathrm{ha}-1+200 \mathrm{~kg}$ Urea ha-1 in Inceptisol at Bontonomo, Gowa, South Sulawesi, has been able to produce the corn yield more than 10 ton ha-1 [58].

Nitrogen serves to stimulate vegetative growth and provide color green on the leaves. In plant leaves, $40 \%$ of the total nitrogen is chloroplast [59]. In addition, nitrogen is a regulator of the use of potassium, phosphorus and other compilers. Lack of plants nitrogen will grow stunted and have a system limited rooting. Leaves will also be yellow or yellowish green and tend fall out quickly [60]. (Nurdin et.al., 2009). Nutrient levels very low nitrogen in the soil. Low the level of nitrogen in the soil is not comparablemthe amount transported by the plant. Therefore, additional nitrogen fertilizer is needed to meet plant needs. Fertilizer nitrogen which is generally available in the Indonesian market is urea.

The results of observations on the weight of 100 grains showed that the application of SRF NPK fertilizer 20-6-10 gives a weighted result of 100 grains which higher at doses of 300 and $400 \mathrm{~kg}$ ha-1 which combined with single fertilizer Urea 100 and $200 \mathrm{~kg}$ ha1, and SRF NPK fertilizer 20-6-10 $200 \mathrm{~kg}$ ha-1 combined with single Urea $200 \mathrm{~kg}$ ha-1 compared to treatment of fertilizer application based on recommendation [61]. According to Bakri [62]. weight of seeds per plant and yield of grains per hectare were significantly affected by the application dose of fertilizer. Additional N, $225 \mathrm{~kg}$ ha-1, will increase weight of seeds per plant and yield of seeds 8.9 ton ha1 to 12.7 ton ha-1. According to [63], $\mathrm{P}$ is very useful for seed formation and it could stimulate the root growth, which play important role in absorbing water and the nutrients. $\mathrm{P}$ is required since early growth, both in vegetative and generative phases.

Nutrient absorption pattern of the corn plant in a season has followed the accumulation pattern of dry matter as described by [64]. Less N, P, and K are absorbed by the plants during the growth in vegetative phase, and nutrient absorption run very quickly during vegetative vegetative phase and seed filling. $\mathrm{N}$ and $\mathrm{P}$ are continuously absorbed by the plants till approaching the maturity phase, while $\mathrm{K}$ is required, particularly in silking. Most of $\mathrm{N}$ and $\mathrm{P}$ are transported to the growing points, stem, leaf, and starninat, and then turned to the seeds. 2/3-3/4 K was left behind in the stem. So that $\mathrm{N}$ and $\mathrm{P}$ may be transported from the soil through seeds during harvest time, and $\mathrm{K}$ was removed through straws (stem). Returning the straw wastes is very important as nutrient supplier. Among different dose of treatments, fertilizer application has significant effect on weight of 100 seeds. Additional NPK fertilizer, both single and complex, will increase $\mathrm{P}$ and $\mathrm{K}$ absorption to the seeds than to stover corn. According to [65], the application of inorganic fertilizer via soils has not completely been able to be absorbed by the plants because the nutrients have been leached and evaporated.

The application of dolomite does not only add $\mathrm{Ca}$ and $\mathrm{Mg}$, but also increase other nutrients supply and improve the physical properties of the soils in order to promote optimal growth of the plants [52].

The right liming will give good results because dolomite contains Ca elements which can increase soil $\mathrm{pH}$. According to [29], the function of $\mathrm{K}$ for plants is to trigger enzyme activity and play a role in seed formation. The more seeds that are formed, the heavier the cob will be. In accordance with the opinion of [66]. who said that $\mathrm{K}$ stimulates the translocation of carbohydrates from leaves to other plant organs, especially carbohydrate storage of plant organs. The availability of sufficient nutrients, especially potassium, can increase the size of the perfect cob so that it will affect the yield of weight and seeds of [67].

\subsection{Relative Agronomic Effectiveness (RAE) Value.}

Effectiveness of the fertilizers was showed by the Relative Agronomic Effectiveness (RAE) toward standard fertilizer as recommended. In this experiment, the standard treatment used treatment B that was 300 $\mathrm{kg}$ Urea ha-1 + $400 \mathrm{~kg}$ NPK Phonska ha-1 (RRIF). Yield of dry seeds of corn on the treatment was used as standard of RAE $100 \%$. Results of RAE analysis in relation to the effect of dolomite brand "Rubi" 
application on growth and yield of corn are presented in Table 7.
Fertilization treatment using 1, 2, 3, and 4 tons of dolomite brand "Rubi" ha-1 combined with $300 \mathrm{~kg}$

Table 7. Relative Agronomic Effectiveness (RAE) Values of fertilizer application of dry seeds yield of corn

\begin{tabular}{|c|l|l|l|}
\hline Code & Treatments & $\begin{array}{l}\text { Dry seeds yield of corn } \\
\text { with water content 14\% } \\
\text { (ton ha-1) }\end{array}$ & $\begin{array}{l}\text { Relative Agronomic } \\
\text { Effectiveness (RAE) (\%) }\end{array}$ \\
\hline A & $\begin{array}{l}0 \mathrm{~kg} \text { Urea/ha + } \\
\text { dolomite brand "Rubi" ha-1 }\end{array}$ & - \\
\hline B & $\begin{array}{l}300 \mathrm{~kg} \text { Urea ha-1 + 400 kg NPK } \\
\text { Phonska ha-1 (RRIF) }\end{array}$ & 6,20 & 100 \\
\hline C & $\begin{array}{l}\text { RRIF + 1 tons dolomite brand } \\
\text { "Rubi" ha-1 }\end{array}$ & 6,45 & 112,63 \\
\hline D & $\begin{array}{l}\text { RRIF + 2 tons dolomite brand } \\
\text { "Rubi" ha-1 }\end{array}$ & 6,84 & 132,32 \\
\hline E & $\begin{array}{l}\text { RRIF + 3 tons dolomite brand } \\
\text { "Rubi" ha-1 }\end{array}$ & 7,23 & 152,02 \\
\hline F & $\begin{array}{l}\text { RRIF + 4 tons dolomite brand } \\
\text { "Rubi" ha-1 }\end{array}$ & 7,68 & 174,75 \\
\hline
\end{tabular}

The calculation results of $\mathrm{RAE}$ showed that $\mathrm{C}=300$ $\mathrm{kg}$ Urea ha-1 + $400 \mathrm{~kg}$ NPK Phonska ha- $1+1$ tons dolomite "Rubi" ha-1, D = $300 \mathrm{~kg}$ Urea ha-1 + $400 \mathrm{~kg}$ NPK Phonska ha- $1+2$ tons dolomite "Rubi" ha-1, E = $300 \mathrm{~kg}$ Urea ha-1 + $400 \mathrm{~kg}$ NPK Phonska ha-1 + 3 tons dolomite "Rubi" ha-1, and F $=300 \mathrm{~kg}$ Urea ha- $1+400$ kg NPK Phonska ha-1 + 4 tons dolomite "Rubi" ha-1 have Relative Agronomic Effectiveness (RAE) values are more than $100 \%$, namely $112.63 \%, 132.32 \%$, $152.02 \%$, and $174.75 \%$, respectively. Those four treatments, C, D, E, and F used dolomite brand "Rubi" for about 1, 2, 3, and 4 ton ha-1, and they effectively increased the dry seeds yield of corn. It was showed by Relative Agronomic Effectiveness (RAE) value more than $100 \%$.
Urea ha-1 + $400 \mathrm{~kg}$ NPK Phonska ha-1 (treatments C, D, E, and F)) obtained a value of Relative Agronomic Effectiveness or RAE is greater (>) $100 \%$. According to [68], the RAE value which is more than $100 \%$ means that the tested fertilizer is more effective than the standard fertilizer yield.

The highest effectiveness reached $174.75 \%$ by the treatment F $=300 \mathrm{~kg}$ Urea ha-1 + $400 \mathrm{~kg}$ NPK Phonska ha-1 +4 tons dolomite"Rubi" ha-1. The application of dolomite brand "Rubi" ha-1 combined with the Recommended Rates of Inorganic Fertilizers or RRIF (300 kg Urea ha-1 + $400 \mathrm{~kg}$ NPK "Phonska" ha-1 )

Table 8. Financial analysis on farming by the fertilizer application on yield of maize over the area one $(1,0)$ Hectare, Rainy Season I, 2018-2019, Kediri District, (x IDR.000)

\begin{tabular}{|c|c|c|c|c|c|c|}
\hline \multirow{2}{*}{ Treatments } & \multirow{2}{*}{$\begin{array}{l}\text { Dry seeds yield of } \\
\text { corn (tons ha-1) }\end{array}$} & \multicolumn{2}{|c|}{ Cost (IDR) } & \multirow{2}{*}{$\begin{array}{l}\text { Gained gross } \\
\text { income } \\
\text { (IDR) }\end{array}$} & \multirow{2}{*}{$\begin{array}{l}\text { Net income } \\
\text { (IDR) }\end{array}$} & \multirow[b]{2}{*}{$\begin{array}{l}\mathrm{R} / \mathrm{C} \\
\text { ratio }\end{array}$} \\
\hline & & $\begin{array}{l}\text { Total Means of } \\
\text { Production }\end{array}$ & Total Labor & & & \\
\hline A & 4.22 & 2,368 & 7,108 & 18,568 & 9,092 & 1.95 \\
\hline B & 6.20 & 3,720 & 7,900 & 27,280 & 15,660 & 2.44 \\
\hline C & 6.45 & 4,220 & 7,650 & 28,380 & 16,510 & 2.39 \\
\hline D & 6.84 & 4,720 & 8,156 & 30,096 & 17,220 & 2.34 \\
\hline$E$ & 7.23 & 5,220 & 8,312 & 31,812 & 18,280 & 2.35 \\
\hline $\mathrm{F}$ & 7.68 & 5,720 & 8,492 & 33,792 & 19,580 & 2.38 \\
\hline
\end{tabular}

Notes : Price : Urea $=$ IDR 1,800,- $\mathrm{kg}^{-1} ; \mathrm{NPK}=\mathrm{IDR} 2,300,-\mathrm{kg}^{-1} ;$ dolomite brand "Rubi" $=\mathrm{Rp} .500 \mathrm{~kg}^{-1}$; Selling corn dry seeds is IDR 4.400,$\mathrm{kg}^{-1}$ in Kediri District in January 2019. It is assumed that the production cost is equal except fertilizer and harvest costs; Net income is total sale value minus fertilizer cost, labor costs, productionfacility costs, and harvest cost (IDR $400,-\mathrm{kg}^{-1}$ ) 
has been effective in increased the yield as showed by

RAE value more than $100 \%$.

Table 9. Financial analysis of farming by the fertilizer application on yield of maize over the aerea one $(1,0)$ Hectares used $300 \mathrm{~kg}$ Urea ha-1 $+400 \mathrm{~kg}$ NPK Phonska ha ${ }^{-1}$ (RRIF) (B) and $300 \mathrm{~kg}^{-}$Urea ha $^{-1}+400 \mathrm{~kg}$ NPK Phonska ha-1 +4 tons dolomite brand "Rubi" ha-1 (F), rainy season I, 2018-2019, Kediri District (x IDR. 000)

\begin{tabular}{|c|c|c|c|c|c|c|}
\hline \multicolumn{2}{|c|}{ Activity } & \multirow{2}{*}{$\begin{array}{r}\text { Price Unit } \\
\text { (IDR) }\end{array}$} & \multicolumn{2}{|c|}{$\begin{array}{l}300 \text { kg Urea ha-1 + } 400 \\
\text { kg NPK Phonska ha-1 } \\
\text { (RRIF) (B) }\end{array}$} & \multicolumn{2}{|c|}{$\begin{array}{l}300 \text { kg Urea ha-1 + } \\
400 \text { kg NPK Phonska } \\
\text { ha-1 + } 4 \text { Tons Dolomit } \\
\text { "Rubi" ha-1 (F) }\end{array}$} \\
\hline A. & Labor WWD,MWD) & & Unit & $\begin{array}{l}\text { Price Unit } \\
\text { (IDR) }\end{array}$ & Unit & $\begin{array}{c}\text { Price Unit } \\
\text { (IDR) }\end{array}$ \\
\hline 1. & Tillage & 35 & 30 & 1,050 & 30 & 1,050 \\
\hline 2. & Planting & 35 & 25 & 875 & 25 & 875 \\
\hline 3. & Weeding and Filling I & 35 & 11 & 385 & 11 & 385 \\
\hline 4. & Weeding and Filling II & 35 & 11 & 385 & 11 & 385 \\
\hline 5 & Weeding and Filling III & 35 & 15 & 525 & 15 & 525 \\
\hline 5. & Fertilization & 35 & 10 & 350 & 10 & 350 \\
\hline 6. & Spraying & 50 & 10 & 500 & 10 & 500 \\
\hline 7. & Harvest & Wholesale & & 2,48 & & 3,072 \\
\hline 8. & Post Harvest & 45 & 15 & 675 & 15 & 675 \\
\hline 9. & Dryer & 45 & 15 & 675 & 15 & 675 \\
\hline \multicolumn{2}{|c|}{ Total Labor } & & & 7,9 & & 8,492 \\
\hline \multicolumn{7}{|c|}{ B. Production Facility } \\
\hline 1. & Seed (kg) & 83 & 20 & 1.660 & 20 & 1,660 \\
\hline 2. & Dolomite brand "Rubi" (kg) & 500 & - & - & 4 & 2 \\
\hline 3. & Urea (kg) & 1.8 & 300 & 540 & 300 & 540 \\
\hline 4. & NPK Phonska (kg) & 2.3 & 400 & 920 & 400 & 920 \\
\hline 5. & Pesticide & 0.6 & 10 & 600 & 10 & 600 \\
\hline \multicolumn{2}{|c|}{ Total Means of Production } & & & 3,720 & & 5,720 \\
\hline \multicolumn{2}{|c|}{ Total Cost Production } & & & 11,620 & & 14,212 \\
\hline \multicolumn{2}{|c|}{ Dry seeds yield of corn (ton ha-1) } & & & 6.20 & & 7.68 \\
\hline \multicolumn{2}{|c|}{ Gained gross income (IDR) } & & & 27,280 & & 33,792 \\
\hline \multicolumn{2}{|c|}{ Net income (IDR) } & & & 15,660 & & 19,580 \\
\hline \multicolumn{2}{|c|}{$\mathrm{R} / \mathrm{C}$ ratio } & _ & & 2.44 & & 2.38 \\
\hline \multicolumn{2}{|c|}{$\mathrm{B} / \mathrm{C}$ ratio } & & & 1.74 & & 1.73 \\
\hline
\end{tabular}

Note : WWD = Women's Work Day; MWD = Men's Work Day; Notes : Price : Urea $=$ IDR $1,800,-\mathrm{kg}^{-1} ; \overline{\mathrm{NPK}}=$ IDR 2,300,- $\mathrm{kg}^{-1}$; dolomite "Rubi" = Rp. $500 \mathrm{~kg}^{-1}$; Selling corn dry seeds is IDR 4.400,- $\mathrm{kg}^{-1}$ in Kediri District in January 2019. It is assumed that the production cost is equal except fertilizer and harvest costs; Net income is total sale value minus fertilizer cost, labor costs, productionfacility costs, and harvest cost (IDR $400,-\mathrm{kg}^{-1}$ ) 


\subsection{Analysis on Corn Farming per Hectare in Kediri District, Rainy Season I, 2008-2019.}

Profit rate and efficient farming are indicator of success in farming or properness of the farming technology that being managed. In order to determine the profitable dosage fertilizer, input - output analysis was conducted by an assumption that the calculated production cost is cost for providing production means and fertilizer application and harvest cost, whereas miscellaneous costs are assumed equal for all treatments. Financial analysis of maize farming is presented in Table 8.

Selling price of corn is IDR 4.400,- kg- 1 . In this analysis, change or additional cost are calculated as a result of different fertilizer application, farming cost, and output value due to different fertilizer application. Net income (profit) is calculated by reducing the sale value of dry seeds yield of corn and fertilizer cost, as well as harvest cost, and other farming costs (labor costs and cost of production facilities), so that profit of the fertilizer application can be calculated. Results of financial analysis on maize farming in Kediri District over fertilizer treatment of $\mathrm{F}=(300 \mathrm{~kg}$ Urea ha- $1+400$ kg NPK Phonska ha-1 + 4 tons dolomite"Rubi" ha-1) produced the highest dry seeds yield of corn is 7.68 tons ha- 1 , the highest gained gross income is IDR $33,792,000,-$, and the highest net income (profit) is IDR $19,580,000,-$ by R/C-ratio 2.38 . The treatment $\mathrm{B}=$ RRIF (300 kg Urea ha-1 + $400 \mathrm{~kg}$ NPK Phonska ha1) produced dry seeds yield of corn is 6.20 tons ha-1, gained gross income is IDR 27,280,000,-, and net income (profit) is IDR 15,660,000,- by R/C-ratio 2.44 . The lowest fertilizer application is inorganic fertilizer $\mathrm{A}=$ (without fertilizer) produced dry seeds yield of corn is 4.22 tons ha-1, gained gross income is IDR $18,568,000,-$, and net income (profit) is IDR 9,092,000,- by R/C-ratio 1.95 . Whether high or low the gross income gained by the farmers, it depends on the amount of the yield (dry seeds of corn) multiplied by price of dry seeds of corn per $\mathrm{kg}$ and minus production cost (cost of workforces and cost of production means).

In order to find out further efficiency level of fertilization, financial analysis on farming of corn was conducted against the treatment $\mathrm{F}=300 \mathrm{~kg}$ Urea ha-1 + 400 kg NPK Phonska ha-1 + 4 tons dolomite "Rubi" ha- 1 and the comparative fertilization, treatment $\mathrm{B}=$ $350 \mathrm{~kg}$ Urea ha- $1+400 \mathrm{~kg}$ NPK Phonska ha-1 or RRIF. Financial analysis on farming of corn ha- 1 applied 300 kg Urea ha-1 + $400 \mathrm{~kg}$ NPK Phonska ha-1 or RRIF (B) and $300 \mathrm{~kg}$ Urea ha-1 + $400 \mathrm{~kg}$ NPK Phonska ha-1 +4 tons dolomite "Rubi" ha-1 (F) are presented in Table 9.

The treatment $F=300 \mathrm{~kg}$ Urea ha- $1+400 \mathrm{~kg} \mathrm{NPK}$ Phonska ha- $1+4$ tons dolomite"Rubi" ha-1 has R/C ratio 2.38 , and $\mathrm{B} / \mathrm{C}$ ratio 1.73 , while the treatment $\mathrm{B}=$
$300 \mathrm{~kg}$ Urea ha-1 + $400 \mathrm{~kg}$ NPK Phonska ha-1 (RRIF) has $\mathrm{R} / \mathrm{C}$ ratio $=2.44$ and $\mathrm{B} / \mathrm{C}$ ratio $=1.74$. Net income (profit) by treatment $\mathrm{F}=300 \mathrm{~kg}$ Urea ha- $1+400 \mathrm{~kg}$ NPK Phonska ha- $1+4$ tons dolomite "Rubi" ha- 1 is IDR $19,580,000,-$, while the treatment $B=300 \mathrm{~kg}$ Urea ha-1 + 400 kg NPK Phonska ha-1 (RRIF) is IDR 15,660,000,-. (Table 9). The application of fertilizer 300 kg Urea ha-1 + 400 kg NPK Phonska ha-1 (RRIF) +4 tons dolomit "Rubi" ha-1 is considered profitable because $\mathrm{B} / \mathrm{C}$ ratio $>1$.

The amount of gross income depends on amount of the yield (dry seeds of corn) multiplied dry seeds of corn price kg-1 minus the production costs (labor costs and cost of production facilities). In general, the technology of fertilizer application using dolomite brand "Rubi" is prospecting and should be developed. It can be seen from $\mathrm{R} / \mathrm{C}$ ratio, which is higher than 1 $(>1)$. It showed that the fertilizer application technologi, which is introduced to the farmers, is economically worth it and good enough. $\mathrm{R} / \mathrm{C}$ ratio or $\mathrm{B} / \mathrm{C}$ ratio is profitable if $\mathrm{R} / \mathrm{C}$ ratio or $\mathrm{B} / \mathrm{C}$ ratio is higher than one. $\mathrm{R} / \mathrm{C}$ ratio or $\mathrm{B} / \mathrm{C}$ ratio $>1$ means that the business has run efficiently [10]. It can be said that from farming operation side, technology that applying soil conditioner of biochar, from maize ear and rice hull, is worth to be developed.

The profit and cost aspect in farming operation is important to be considered, whereas the maize farmers usually have limited cost and low productivity. It is expected that each farming technology can be adopted by the farmer. Therefore, in order to be easily adopted by the farmers, such technology should be easily applicable and profitable [69].

\section{CONCLUSION}

The results showed that the application of $\mathrm{F}=300$ kg Urea ha-1 + 400 kg NPK Phonska ha-1 + 4 ton dolomite brand "Rubi" ha-1 in Kediri District obtained better growth components (plant height, stem diameter, Leaf Area (LA), and Leaf Area Index (LAI)) and yield components (number of seed per cob, weight of 100 seeds, weight per cob, and dry seeds yield of corn) in comparison with other treatments.

The results showed that the application of $\mathrm{F}=300$ kg Urea ha- $1+400$ kg NPK Phonska ha- $1+4$ tons dolomite brand "Rubi" ha-1 obtained the highest dry seeds yield of corn 7.68 ton ha- 1 or increase of $23.87 \%$ from the RRIF, obtained the highest net income (profit) IDR 19,580,000,- or increase of $25.03 \%$ from the RRIF, $\mathrm{R} / \mathrm{C}$ ratio 2.38 , and $\mathrm{B} / \mathrm{C}$ ratio 1.73

The application of dolomite "Rubi" on corn gained $\mathrm{R} / \mathrm{C}$ ratio $>1$, so that it is technically deserved to be developed and gained $\mathrm{B} / \mathrm{C}$ ratio $>1$, so that it is economically profitable. The treatment $\mathrm{F}=(\mathrm{RRIF}+4$ ton dolomite"Rubi" ha-1), showed the effectiveness of 
174.75\% by Relative Agronomic Effectiveness (RAE) $>100 \%$.

\section{REFERENCES}

[1] H.D. Foth. 1994 Fundamentals of translated soil science (Translate by Adisoemarto S) Edition VI Erlangga Jakarta

[2] R. Kartono. 2010 Dolomite A100 fertilizer product catologist passed $96 \%$ North Sumatera http://agrounited.wordpress.com/about Accessed July 10, 2021

[3] Kuswandi 1993 Liming Agricultural Sciences Kanisius Yogyakarta p 92

[4] A. Prayitno. 2015 The Response of Dolomite Lime and Modern Granule Organic Fertilizer to the Growth and Yield of Shallots (Allium Ascalonicum L.) on Sandy Soil Essay Muhammadiyah Palangkaraya University

[5] I. Putra, Jasmi, O. Setiawan. 2018 Effect of dolomite and fertilization on okra growth and yield (Abelmoschus esculentus L) Journal of Agrotek Lestari 5 47-60

[6] B.Chutichudet, P. Chutichudet, S. Kaewsit. 2010. Effect of dolomite application on plant growth, activities of polyphenol oxidase and internal quality of grand rapid lettuce. Int J Agric Res 5 (9): 690-707

[7] G.C. Cresswell, R.G. Weir, 1997. Plant Nutrient Disorders 5: Ornamental Plants and Shrubs. Inkata Press, Melbourne, ISBN-13: 978-0-909605-93-3

[8] Z. Rengel., 1992. The role of calcium in salt toxicity. Plant Cell Environ., 15: 625-632.

[9] R. De Mello Prado., W. Natale, J.A.A. Silva, 2005. Liming and quality of guava fruit cultivated in Brazil. Scientia Hortic., 106: 91-102.

[10] E.J. Hanson, W.J. Bramlage, R.A. Cline, M.M. Kushad, 1991. Calcium accumulation in Delicious apple fruit. J. Plant Nutr., 14: 1213122.

[11] V. Kovačević, M. Rastija. 2010. Impacts of liming by dolomite on the mays and barley grain yields. POLJOPRIVREDA $163-8$.

[12] Gomez 1995 "Statistical procedurs for agricultural research (Translate by Endang Sjamsuddin and Yustika, Baharsjah S)" 2nd Edn UI Press, Jakarta

[13] A. Sastrosupadi. 2005 Practical Experiment Design in Agriculture Kanisius Yogyakarta p 243

[14] Regulation of the Minister of Agriculture Number 70/ Regulation of the Minister of Agriculture/SR.140/10/2011 Organic fertilizers, biological fertilizers and soil enhancers
[15] A.D. Machay, J. K Syers, P.E.H Gregg .1984 Ability of chemical extraction procedures to assess the agronomic effectiveness of phosphate rock material New Zealend Journal of Agricultural Research 27219 - 230.

[16] Soekartawi, A. Soeharjo. 2011 Farming science and research for smallholder development (Jakarta: UI Press)

[17] H. Hardjowigeno. 1995 Ilmu Tanah Medyatma Sarana Perkasa Press p 248

[18] M.D. Mullen. 1999 Transformation of other elements. In principles and applications soil microbiology Prentice-Hall New Jersey p 19

[19] M.Y. Nyakpa, A.M. Lubis, M.A, Pulung A.G, Munawar, G.B Hong, N. Hakim. 1988. Soil Fertility Lampung University p 258

[20] Syafruddin. 2016. Site-specific fertilization of N, $\mathrm{P}$, and $\mathrm{K}$ on maize in Gowa Regency South Sulawesi Journal of the Assessment and Development of Agricultural Technology 19119 $-133$

[21] A. Heggenstaller. 2016. Crop insights: managing soil $\mathrm{pH}$ for crop production. http://www.pioneer.corn/home/site/us/agronomy/ library/managingsoilpH/Accessed July 5, 2021

[22] Ermadani. 2010. Improvement of soil chemical properties of Ultisols and Calopogonium growth with liming and fertilization of $\mathrm{N}, \mathrm{P}$ and $\mathrm{K}$. Research Journal Jambi University Science Series 12 07-12

[23] K.S. Chukwuka, S. Ajala, P.C. Nwosu, O.E. Omotayo, 2015. Effects of NPK single fertilizers on relative growth performances of two cycles of maize (Zea mays L.) grown in a degraded soil of Southwest Nigeria. Journal of Agronomy 14203 211

[24] Sugiono, A. Krismawati. 2020. Potency of maize production by the application of NPK (15-10-20) fertilizer and organic fertilizer on irrigated field dry season 1. OP Conf. Series: Earth and Environmental Science 456 (2020) 012089 IOP Publishingdoi:10.1088/17551315/456/1/012089. p. 1-9.

[25] L.A. Noza, H. Yertti, A.A Khoiri. 2014. Effect of dolomite and $\mathrm{N}, \mathrm{P}, \mathrm{K}$ fertilizers on growth and production of sweet corn (Zea mays saccharata Sturt) on peat land Journal of JOM Faperta 11 $-11$

[26] S. Rosita, M. D. Raharjo, Kosasih. 2007. Growth pattern and nutrient uptake of $\mathrm{N}, \mathrm{P}$, and $\mathrm{K}$ of Bangle Plants Research Center for Medicinal Plants and Spices http://digiliblipi.go.od/view.html?idm=39615 Accessed on May 17, 2021 
[27] A.S Ibrahim, A. Kasno. 2008. Interaction of lime application on fertilization urea on soil $\mathrm{N}$ content and $\mathrm{N}$ uptake in corn (Zea mays. L). Soil Research Institute. Bogor.

[28] A. Doberman, T. Fairhust. 2000. Rice Nutrient Disorders \& Nutrient Management. International Rice Research Institute (IRRI) Zinc Deficiency And Potash \& Phosphate Institute/Potash \& Phosphate Institute of Canada pp 84-87

[29] B. Lakitan. 2010. Plant Physiology and Plant Development Raja Grafindo Persada Jakarta $\mathrm{p}$ 205

[30] P. Lingga. 2001. Instructions for Use of Fertilizer Penebar Swadaya Jakarta $\mathrm{p} 30$

[31] A.H. Fitter, R.J.M. Hay. 1994 Plant Environmnetal Physiology Gajah Mada University Press Yogyakarta

[32] H. Nurhayati, M. Y Nyakpa., AM Lubis., S.G Nugroho, M. R. Saul, M. A Diha., Go Ban Hong, H. H. Bailey. 1986. Basic of Soil Science Lampung University p 488

[33] A. Aisyah, I. W. Suastika, S. Retno. 2017. Effect of application of several sulfur fertilizers on residue,uptake and production of maize at Mollisol Jonggol, Bogor Journal of Land and LandResources 2 93-101

[34] A. Poerba, I. Rosalyne, Suryadi. 2020. Effect of dolomite dose and potassium fertilizer dose on growth and production of Bisi-2 hybrid maize (Zea mays L) hibrida Bisi-2 Journal of Rhizobia Scientific $289-100$

[35] A.S. Ibrahim, A. Kasno. 2008. Interaction of offering lime on fertilization urea on soil $\mathrm{N}$ content and $\mathrm{N}$ uptake in corn plant Soil Research Institute Bogor

[36] Ramli. 2014. Efficiency of cow manure and NPK compound fertilizer on growth and production of pare (Momordica charantia L) University Tamansiswa Padang West Sumatera

[37] F.P.B. Gardner, Pearce, R. Mitchell. 2008. Physiology of Cultivated Plants. UI Press pp 428

[38] Novizan. 2002. Effective Fertilization Instructions Agromedia Pustaka Jakarta

[39] F. Ilham, T.B. Prasetyo, S. Prima. 2019. The effect of dolomite applications on some chemical properties of peat soil and onion plant growth and yield (Allium ascalonicum .L.) Journal of Solum $16 \quad 29-39$

[40] Bilman. 2001. Analysis of corn plant growth, shifts in weed composition at several spacings Indonesian Journal of Agricultural Sciences 325 -30 .
[41] S.M. Sitompul and B. Guritno. 1995. Plant Growth Analysis Gadjah Mada University Press Yogyakarta p 412

[42] S. Kuruseng, Koesriharti, M. Santoso. 2013 Effect of organic fertilizer on growth and yield of sweet corn Journal of Indonesian Green Technology 2 $13-16$

[43] A. Wahyudin, T. Nurmala, R.D. Rahmawati 2015 Effect of dosage of phosphorus and liquid organic fertilizers on growth and yield of green beans (Vigna radiate L.) on Jatinangor Ultisols Journal Kultivar 14 16-22

[44] D. Saragih, H. HamimMand N. Nurmili. 2013. Effect of time and dose on urea fertilizer application in increasing growth and yield of sweet corn (Zea mays L.) Journal of Tropical Agrotek $150-54$

[45] B.J. Effendi. 2011 Effect of foliar fertilizer concentration and bacterial application on Synechococcus sp on photosynthesis rate and patchouli plant biomass production (Pogostemon cablin Benth) Essay Jember University

[46] P. Suratmini. 2009 Combination of urea fertilizer and organic fertilizer on sweet corn on dry land Journal of Agricultural Research of Food Crops $28 \quad 83-88$

[47] P.G. Pusparini, A. Yunus, D. Harjoko. 2018 Dosage of NPK fertilizer on hybrid corn on growth and yield Journal of Agrosains 2028 33

[48] H.A. Putri. 2011. The effect of giving several concentrations of bio complete liquid organic fertilizer on the growth and yield of sweet corn plant (Zea mays saccharata Sturt.) Essay Andalas University Padang West Sumatera

[49] M.P. Sirappa, N. Razak. 2010 Increasing maize productivity through provision of $\mathrm{N}, \mathrm{P}$, and $\mathrm{K}$ fertilizers and manure on dry land in Maluku Proceedings of the National Cereal Week

[50] N. Hidayat. 2008. Growth and production of groundnut (Arachis hypogea L.) Madura local variety at various spacings and dosage of phosphorus fertilizer. Journa of Agrovigor 155 -64 .

[51] N.M. Rahni. 2012 Effects of PGPR (Plant Growth Promoting Rhizhobacteria) phytohormones on corn plant growth Journal of Agribusiness and Regional Development 3 27-35

[52] Syafruddin, Zubachtirodin 2010 Use of Compound 20 - 10 - 10 NPK fertilizers on corn plants Proceedings of the National Cereal Week Cereal Plant Research Institute p $174-187$ 
[53] T. B. Lakshmi, H.C. Prakash, K. Sudhir. 2010 Effect of different sources and levels of sulphur on the performance of rice and maize and properties of soil Journal of Agricultural Sciences $4478-$ 88

[54] Marschner. 2012. Mineral Nutrition of Higher Plants Academic Press London

[55] S.S. Harjadi. 1979 Introduction of Agronomy Gramedia Jakarta

[56] Jumini, Nurhayati, Murzani 2011 The effect of the combination of dosage of $\mathrm{N}, \mathrm{P}, \mathrm{K}$ fertilizers and fertilization methods on the growth and yield of sweet corn Floritek Journal 6 165 - 170

[57] N. Danapriatna. 2008 The role of sulfur for plant growth Journal of Islamic University 45 Bekasi 9 $153-166$.

[58] Syafruddin, Zubachtirodin 2010 Use of Compound 20 - 10 - 10 NPK fertilizers on corn plants Proceedings of the National Cereal Week Cereal Plant Research Institute p 174 - 187

[59] J. M. Paulus. 2013. Green manure application on rice growth and production rice fields in Proceedings National Organic Agriculture. University Gajah Mada. Yogyakarta, August 2829

[60] Nurdin, P. Masspeke, Z. Ilahude, F. Zakaria. 2009. Corn Growth and Yield Fertilized N, P, and K in Soil North Isimu Vertisol, District. Gorontalo. Journal of Tropical Soils 14 49-56

[61] Idaryani and A. Wahid. 2019. Effectivity of SRF NPK 20-6-10 fertilizer on the growth and yield of corn. Journal of Agrisistem. $1550-$ 57.

[62] Bakri 2001. Effect of leachate and municipal waste compost on some physical properties of Inceptisols and maize yield Journal of Agrista $\mathbf{5}$ $114-120$.

[63] A. Wahyudin, Ruminta, D.C. Bachtiar. 2015 Effect of different spacing at various doses of organic fertilizer on growth and yield of P-21 hybrid maize in Jatinangor Journal of Cultivation $141-8$

[64] R.A. Olson, D.H. Sander. 1988 Corn production. In Monograph Agronomy Corn and Corn Improvement Wisconsin pp 639-686

[65] Sumaryo, Suryono 2000 Effect of dolomite and SP-36 fertilizer dosage on number of root nodules and yield of peanut pants in Latosol soil Journal of Agrosains $254-58$

[66] L. Agustina. 1990 Basic Plant Nutrition Rineka Cipta Jakarta p 80
[67] I.G.M. Subiksa. 2012 The effect of planting distance and type of fertilizer on the growth of silage production and hybrid corn seeds in Inceptisols Darmaga Proceedings on Fertilization Technology and Recovery of Degraded Land Agricultural Research and Development Agency pp 349-356

[68] R. Erlambang, W.S.D. Yamika, A. Suryanto 1918 Test the effectiveness of biofertilizers on eggplant plant growth and productivity Journal of Crop Production 62338 - 2345

[69] J. Budianto. 2000 Acceptability of agricultural technology for consumers Food Crops Research Symposium IV Food Crops Research Center Bogor pp 12-13 